\title{
Mythology, Weltanschauung, symbolic universe and states of consciousness
}

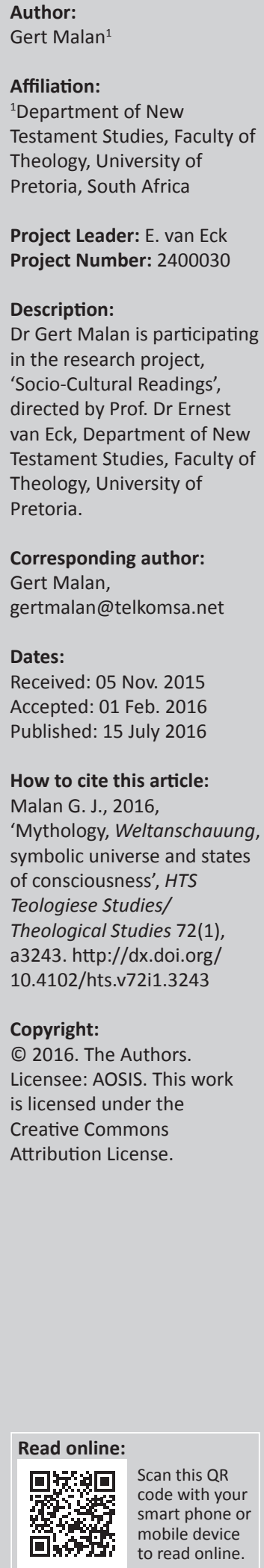

This article investigates whether different religious (mythological) worldviews can be described as alternative and altered states of consciousness (ASCs). Differences between conscious and unconscious motivations for behaviour are discussed before looking at ASCs, Weltanschauung and symbolic universes. Mythology can be described both as Weltanschauung and symbolic universe, functioning on all levels of consciousness. Different Weltanschauungen constitute alternative states of consciousness. Compared to secular worldviews, religious worldviews may be described as ASCs. Thanks to our globalised modern societies, the issue is even more complex, as alternate modernities lead to a symbolic multiverse, with individuals living in a social multiverse.

\section{Myth and mythology}

Myths are narratives explaining how societies came to function as they do. They are part of a society's accepted tradition and relate accounts about the gods and superhuman beings, elucidating customs, institutions and natural phenomena (Gaster 1962:481). The study of myths and their possible interpretations is called mythology. 'Mythology' also describes the total corpus of a culture's myths. Myths are thus narrative threads of which the fabric of a society's mythological cloth is woven. This paper investigates whether mythical frames of reference function as worldviews and symbolic universes, and if they can be understood as alternative and even altered states of consciousness (ASCs).

One stimulus for this article was provided by Andries van Aarde's pragmatic-linguistic reading of Romans 12, concluding that faith is an exceptional religious state of consciousness as a God-given

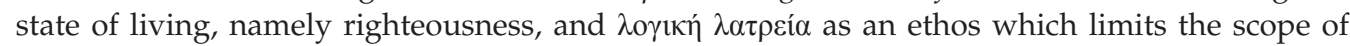
reason to make room for faith, but at the same time demonstrating that belief in God can be rational according to critical philosophy. Romans 12:1-2 contrasts with focus of formal religion on sacrifice by calling for self-sacrifice as contemplating what is good, perfect and pleasing to God thanks to the new relationship with God initiated by God's grace in Christ (Van Aarde 2015:103-109). This complete and ongoing change of mind is what Van Aarde describes as an exceptional religious state of consciousness and refers to acceptance of Paul's mythically clothed kerugma. Van Aarde (2015:98-99) follows William James (1842-1910) who called people's rational trust in and reliance on God (faith) an altered state of consciousness.

Another stimulus for this article is Bultmann explaining the meaning of Paul's conversion as '... die Preisgabe seines bisherigen Selbstverständnisses, d.h. die Preisgabe dessen, was bisher Norm und Sinn seines Lebens, das Opfer dessen, was bisher sein Stolz gewesen war' (Phlp. 3:4-7) (Bultmann [1948] 1980:189). Paul's conversion was neither the result of inner moral collapse, nor a conversion of repentance or emancipating enlightenment, but obedient submission to God's judgment on all human accomplishment and boasting made known in the cross of Christ (Bultmann [1948] 1980:189). His new self-understanding is a new way of thinking about himself and the meaning of his life. Paul's conversion from Judaism to Hellenistic Christianity seems like a new, altered state of consciousness from the previous, implying that the two 'religions' are alternative states of consciousness, and possibly ASCs compared to non-religious consciousness.

In view of these two stimuli, I investigate the possibility that the adherence to different mythologies represent different (alternative) states of consciousness; and whether a religious worldview represents an altered state of consciousness for its adherents, in contrast to people with a secular type of consciousness. The investigation will compare mythologies with worldviews and symbolic universes with a view to clarify their relationship and nuances. But firstly, a short orientation regarding consciousness, the unconscious and ASCs is needed.

1.A next article will focus on mythology as the interpretation of mythical narratives. 


\section{Consciousness}

Consciousness can be described as the first-person world an individual uniquely experiences, which cannot be exactly replicated or accessed by another person (Greenfield 2001:610). Speaking about consciousness per se originated with John Locke's Essay concerning human understanding (1690). Previously, consciousness was understood from its Latin roots (cum scio) denoting joint or shared knowledge; understandings prevalent in a social community (Robinson 2010:782). Consciousness was discussed indirectly in antiquity. Aristotle regarded consciousness as higher-order process and intrinsic feature of mental life (Caston 2002:751-815). ${ }^{2}$ Both natural science (physiology) and humanities (phenomenology and psychology) study consciousness. Their results should not be regarded as mutually exclusive (Taylor 2010:119-130), as science without consciousness as underlying metaphysical concept is impossible (Hennig 2010:15-28).

Consciousness has two main components, namely arousal (the level of consciousness) and awareness (the contents of consciousness). Although usually positively correlated, awareness and arousal involve different brain structures. Arousal is related to the sub-cortical structures around the brain stem reticular formation, hypothalamus and basal forebrain. Awareness involves a widespread set of frontoparietal associative areas on the convexity and the midline. Awareness can be divided into self and external awareness, which are negatively correlated, and each involves an alternate frontoparietal subsystem (Boly et al. 2008:119-122) ${ }^{3}$. This is in line with Baars's conscious access theory (2002:47-52) which views the brain as two parallel sets of specialised processors, with consciousness as the gateway to brain integration, enabling access between otherwise separate neuronal functions. Viewed in this way, central information exchange allows some processors such as the sensory system in the brain, to distribute information to the system as a whole, making coordination and control possible.

The psychological understanding of consciousness has its roots in Descarte's (1595-1650) idea of radical dualism of the material body (res extensa) and unextended mind (res cogitans), man and world, as well as his method of rational doubt. His radical doubting resulted in bracketing the human body and the world, leading to his conclusion:

2.In his treatise "On the soul" (De Anima), Chapter 2, Book 3, Aristotle (trans. 1984:677) speaks of our ability to perceive what our senses perceive from which it follows that perception intrinsically carries conscious awareness. He regards thought and experience as unified, stating that it is impossible to judge separate objects by experience as unified
separate faculties.

3.Regarding awareness, the frontoparietal external awareness network activity is essential for the conscious perception of external stimuli (Boly et al. 2007:12187-12192). The self-awareness frontoparietal network is the 'default network' and is associated with various self-related processes (Fox et al. 2005:9673-9678). There is an anticorrelated pattern of activity present between external and self-awareness networks during cognitive tasks (Gusnard \& Raichle 2001:685-694), sensory perception (Boly et al. 2007:12187-12192), and restingstate brain activity (Fox et al. 2005:9673-9678). During altered states of consciousness activity of both networks are impaired (Boly et al.2008:119-122). Additionlly Additionally, awareness is related to the functional connectivity within the frontoparietal network and with the thalami, which is impaired in vegetative and unconscious states (Laureys et al. 1999a:377-382, 1999b:121, 2000:1790-1791; Massimini et al. 2005:2228-2232, White \& Alkire 2003.402-411) as formulated in the computational model of the relationships between spontaneous brain activity and external stimuli awareness (Dehaene \& Changeux 2005:910-927).
'Sum cogitans cogitationes meas', meaning, I think my own thoughts; I am conscious of the contents of my consciousness and that is what I am (Kruger 1988:12). Consciousness is the characteristic of the person as a whole, continually reflecting on day-to-day experience and being. It is inseparable from their ' $\mathrm{I}$ '; thus an individual can be described as 'a single consciousness and I' from childhood to old age. Also present in an individual is the larger mind of the society in which they grew up, and fundamental metaphysical feelings of truth regarding life and existence (Witz 2015:660-671). Consciousness does not exist other than being the consciousness of a specific person at a certain time and place (Taylor 2010:127), therefore always a subjective experience, of which introspection is a characteristic feature (Feest 2012:1-16). Speaking of consciousness as 'subjective experience' only tangentially captures the forms of life made possible by consciousness. What is distinctive about consciousness is its amenability to rhetorical motivation, moral precepts, forms of art and play, beliefs, convictions, hopes, intuitions, causing behaviour to rise to the level of responsibility which leads to a life of meaning. Consciousness manifests in history in the regulatory prescripts and rules of law, etiquette and ethics of civic society. Civic life necessitates empathy as coconsciousness, a refined and disciplined consciousness which makes the classification of acceptable and unacceptable behaviour possible (Robinson 2010:791-792). Thus, consciousness is intentional, and subjectivity cannot be isolated from intentionality, but should rather be defined in terms of intentionality (Olivier 2011:186-190).

\section{The unconscious}

To understand the unconscious motivations of human behaviour, we turn to Sigmund Freud's psychoanalytical theory, departing from psychic determinism, meaning conscious behaviour and thoughts result from unconscious psychic factors and are thus intentional (Brenner 2007:15; Lothane 2006:287) contra Descartes, as 'mental' does not equal 'conscious' (Lothane 2006:286) and the structure of the psyche (id, ego and superego driven to action by psychic energy in the form of wishes or instincts) (English 2008:240) (see Figure 1).

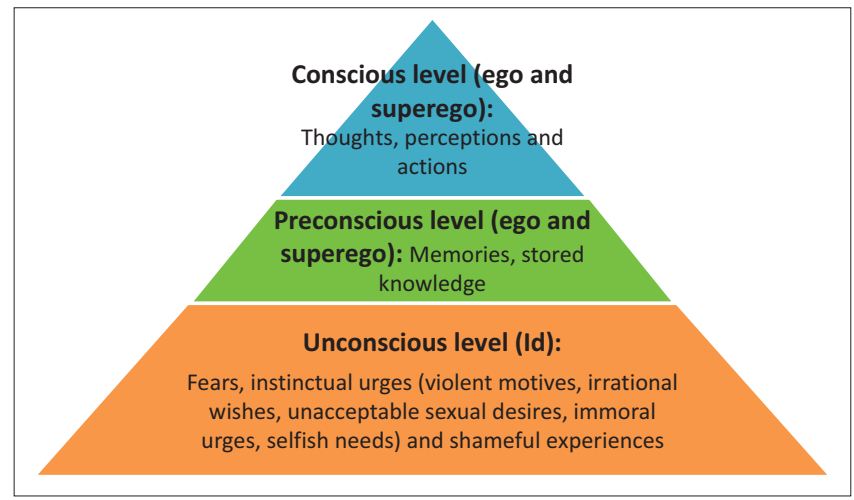

FIGURE 1: Freud's view of psychic determinism relating to levels of consciousness and the structure of the psyche. 
The superego represents perceived societal ideas and values, while the ego is an organised, rational system utilising perception, learning, memory, and so on, for need satisfaction. The id represents the deep inaccessible layer of instinctual urges seeking instant gratification and without values, ethics or logic it obeys the pleasure principle (Bohleber 2011:286; English 2008:240). Some of our instinctual urges (for example sexual and aggressive urges) are already present in childhood and are repressed as against societal norms (English 2008:239; Lothane 2006:286). Such repression results in psychic problems (Power 2000:213). The ongoing conflict between societal norms and instinctual urges being repressed leads to guilt (English 2008:239). There are three levels of consciousness:

1. Conscious level: conscious thoughts, feelings and perceptions, actions;

2. the pre-conscious (subconscious) or 'transient' level of consciousness (Plaut 2005:71) (unrepressed memories and feelings and perceptions not focused on; intermediary between conscious and unconscious (Gammelgaard 2003:14-15) and

3. the unconscious level: repressed instinctual urges, guilt laden wishes and painful memories (Krauze 2011:283; Meyer 1988:43-44; Phares 1992:64-69; Stoycheva \& Weinberger 2014:101).

Freud's psychology is a depth psychology, meaning the mind extends beyond immediate awareness (Ekstrom 2004:662-664) and suggesting that a person's inner life is layered. The unconscious is the dynamic and deepest layer (Lothane 2006:285). This implies that the person concerned does not know what is going on in this sphere of his mind. The conscious is regarded as a superficial layer and the laws governing the conscious do not apply to the unconscious, resulting in tension. Furthermore, the unconscious represents authentic and true man, stripped of layers of conventions and his conscious self-image. This leaves consciousness to be explained by the unconscious, as the authentic drives of human existence are found in the unconscious (Kruger 1988:126-127; also Lothane 2006:286).

\section{Altered states of consciousness}

ASCs are subjective changes in an individual's pattern of mental functioning ${ }^{4}$ such as sensations, perceptions, cognition, memory, sense of self, identity, body, environment (time and space), other people emotions, attention, perception, inner speech, arousal and volition, qualitatively different to normal waking consciousness or relative to a baseline state of consciousness (Bourguignon 1979:236; Erickson \& Rossi 1981:242, 248; Pilch 2004:2; Polito, Langdon \& Brown 2010:919). Examples of such states abound: dreaming, sleeping, hypnagogic state (drowsiness before falling asleep), hypnopompic state (semi-consciousness before waking) regression, meditation, trance, sensory deprivation, dissociative states, reverie, daydreaming, internal scanning, stupor, coma, stored memory, expanded consciousness, hallucinations and states induced by psychoactive substances (Krippner 1972:1-5; Polito et al. 2010:919). The range of phenomena reveals they are commonly experienced and there are different levels of ASCs. During altered states different levels of 'normal' consciousness may be experienced. Some, like trance or sleep, are deeper than daydreaming. Even specific altered states have different levels according to phases that may characterise the state, such as the stages of trance (Pilch 2002:694-697; Polito et al. 2010:919).

ASCs are also called non-consensual reality in contrast to culturally normal reality, which is consensual. Nonconsensual or alternate reality is where gods and spirits can be met when entering an altered state of consciousness such as an ecstatic trance journey (Malina \& Rohrbaugh 2003:327328). The term 'altered state' can be misleading, since it implies a continuity of everyday consciousness. Research on how the brain functions regarding associative connections shows that even the apparent continuity of consciousness in everyday normal awareness is a precarious illusion (Pilch 2002:691 referring to Milton Erickson).

In $90 \%$ of 488 societies around the globe, with different levels of complexity, ASCs were utilised (Bourguignon 1974:229-232). The implication is that only $10 \%$ of the world's population do not utilise common alternate states of consciousness (Groenewald 2011:2). Following Arthur Kleinmann, Pilch (1993:231-244) explains that only secular Western postEnlightenment culture has blocked most of these otherwise panhuman dimensions of the self. The bio-psycho-spiritual unity of human consciousness was disrupted by the advent of science around the seventeenth century. This resulted in Westerners developing an 'acquired consciousness' whereby we dissociate self and look at self 'objectively'. A meta-self is developed as part of Western culture's socialising of individuals. This metaself does not allow total absorption into ASCs, as it stands in the way of unreflected, unmediated experience.

Alternate states of consciousness include basic religious experiences. Jonanda Groenewald (2011:1-10) concludes that participation in the earliest Eucharist implied the experience of an alternate state of consciousness as sharing a meal with Christ as well as already entering into the kingdom of God. Early Christians' apocalyptic worldview enhanced the experiencing of 'another time', the time of God, as breaking into ordinary time, which she rightly calls an altered state of consciousness. According to John Pilch, ASCs fills the Bible pages from Adam's deep sleep (Gn 2:21) to John the Revealer's trance visions. Especially the Acts of the Apostles abound with examples of people experiencing ASCs, of which Peters' vision (Ac 10:1-8) and Paul's conversion (Ac 9:1-19; 22:3-21 and 26:9-18) are two examples (Pilch 2000:690-707). In this regard it is important to realise that 'consciousness' as used here is a Western construct applied as a hermeneutic mechanism to understand ancient Mediterranean states of mind, and was not then viewed in this way. 
Research by cognitive neuroscientists d'Aquili and Neuberg on ecstatic trance led them to the following conclusion about the deep trance state with the experience of absolute unitary being:

\begin{abstract}
... we must conceive the brain as a machine that operates upon whatever it is that fundamental reality may be and produces at the very least two basic versions, both accompanied by profound subjective certainty of their objective reality. Thus, it seems that both God and our everyday world can be perceived by the brain and generated by the brain. At this level of analysis both statements are probably equally true. Whatever is anterior to the experience of God and the multiple contingent reality of everyday life is in principle unknowable, since that which is in any way known must be a transformation wrought by the brain. (d'Aquili \& Neuberg 1999:202; see also Callicott 2011:513; Pilch 2000:704)
\end{abstract}

\section{Worldview [Weltanschauung]}

The term 'worldview' or Weltanschauung is a quintessentially German philosophical term first used by Immanuel Kant (1724-1804) - see Karilemla 2015:251), who established the epistemological foundations of the worldview concept. Kant rendered 'reality' phenomenal and potentially plural. Kant thus caused a Copernican revolution in philosophy by making the human mind the centre, if not the location of the cosmos. We perceive things in this world not as they are in themselves ('noumena'), but as they appear ('phenomena'), because our senses act as filters for our consciousness. Because all humans share the same sensory, spatio-temporal and cognitive filters through which phenomena appear to us, all humans share the same 'reality' (Callicott 2011:510-513; Kant [1781] 1984:180-232).

Since Kant the term Weltanschauung has been an important part of the debate about the subject matter studied by philosophy. Hegel maintained that philosophy was 'its own time comprehended in thought' (Hegel [1820] 1991:21), suggesting that philosophy should be the disciplined clarification of the prevailing Weltanschauung. In Hegel's view, Weltanschauung was the worldview of a certain nation at a certain time. It is a shared view which is automatically acquired by social participation (McCarthy 1978:136). Nietzsche saw worldview as the general conception of life of an individual or a people, which Nietzsche considered as the vital horizon for human existence (Nietzsche [1874] 1980:10), because the only view and therefore the only knowledge we have is from a certain perspective (Nietzsche [1887] 2009:98). As Nietzsche often equated horizon with perspective, this means that we understand phenomena only from the standpoint of our own worldviews. The implication is that we are locked within our worldviews (Karilemla 2015:251). Heidegger, on the other hand, distinguishes sharply between philosophy and worldview. There was a distinct development of Heidegger's views on worldview. Early in his career Heidegger's concern for facticity was tied to his thoughts about worldview. Later on, in Sein und Zeit (1933-1934), he considered worldview to be a fixed interpretation of the universe of beings. Eventually his view of worldview was influenced by the technological understanding of being and his notion was that worldview was the picturing or representing of beings as a whole to themselves (Karilemla 2015:250-266).

Following Husserl, Heidegger overcomes the subject-object dichotomy. Therefore, to refer only to Heidegger's use of the term Weltanschauung as object does not do justice to his existential phenomenology, nor to the bond which we have with our perceived world. Heidegger's description of man in the world is essential to understand the existential functioning and effect of worldview. Man, or rather Dasein, cannot be defined without referring to the world, neither can the world be defined without referring to Dasein (Heidegger [1927] 1996:49-58). There is a definite relatedness and unrepeatable cohesion with our fellow humans and the things in the world. There is no separateness of man in the world. Worldview is thus not only a frame of reference, but our relatedness to the world and others (Mitdasein and Einfühlung) (Heidegger [1927] 1996:107-137). There is no other existence apart from being in the world and sharing it with others (Mitwelt) (Heidegger [1927] 1996:110-122) and having our lives structured by this world of ours and our relatedness with others (Kruger 1988:30-91). Conclusion: The world is not something out there, but our unique relatedness to it; it is the world as we live, structure and perceive it, thus we are essentially our world. In the same way worldview is not something apart from us, but the view of our relatedness to the world and the meaning of our existence in the world with others. Worldview is an existential and thus uniquely individual expression, shared with but not identical to others' worldviews, which confirms the plurality of worldview.

Freud formulated an extensive and insightful definition of Weltanschauung towards the end of his life. In his work New introductory lectures on psychoanalysis (1933) Freud devoted the last chapter to Weltanschauung, which he defined as
... an intellectual construction which solves all the problems of our existence uniformly on the basis of one overriding hypothesis, which, accordingly, leaves no question unanswered and in which everything that interests us finds its fixed place. It will easily be understood that the possession of a Weltanschauung of this kind is among the ideal wishes of human beings. Believing in it, one can feel secure in life, one can know what to strive for, and how one can deal most expediently with one's emotions and interests (Bergmann 2010:53-54; Freud[1933] 1971:158).

Despite this extensive definition, Freud's thoughts on worldview ran into a difficulty. According to Freud, psychoanalysis did not have a worldview of its own, but shared the worldview of science, but he realised that science cannot claim to be a worldview either. He rejected philosophy's ideas of worldview as an illusion of being able to present a picture of the universe without gaps and ended by advocating the 'dictatorship of reason' as best solution (Bergmann 2010:54; Freud [1933] 1971:171).

Social scientists discovered that, despite sharing the same sensory, spatio-temporal and cognitive biological filters, 
our human classificatory and organising frames of reference vary between individuals and, even more so, between different cultures. Our conceptual frameworks are the result of cultural education, leaving humanity with a multitude of diverse worldviews (Callicott 2011:514-515).

Peter Berger aptly states: 'Every human society is an enterprise of world-building' (Berger 1973:13). This is also true of the global society. It is a society developing from mainly Western and American inspiration and it encompasses diverse cultures forming a truly global culture. The global society is a layered one, but not along traditional cultural lines. There are different varieties of elites, such as the business elite (the so-called 'Davos culture') and the globalised intelligentsia, but also popular manifestations. Modernising is one of the primary characteristics of the global culture. It perceives itself and is perceived by others to be distinctly modern and therefore in conflict with traditional beliefs, values and lifestyle. A byproduct is individuation: modernisation throws individuals from their traditional identities on their own resources. Fortunately the global culture provides context and meaning and makes the stressful process of individuation bearable. Another important aspect of globalisation is the phenomenon of alternate modernities. Individuals from traditional religious communities adapt to a highly technological environment and the global village without relinquishing any of these 'worlds' (Berger 2003:4-10). In this sense, it seems inappropriate to speak of such individuals as having $a$ worldview, because in their case more than one diverse worldview is functioning alongside others.

Alternate modernities suggest diverse worldviews could span the social world of individuals and can be illustrated in the following diagram (Figure 2).

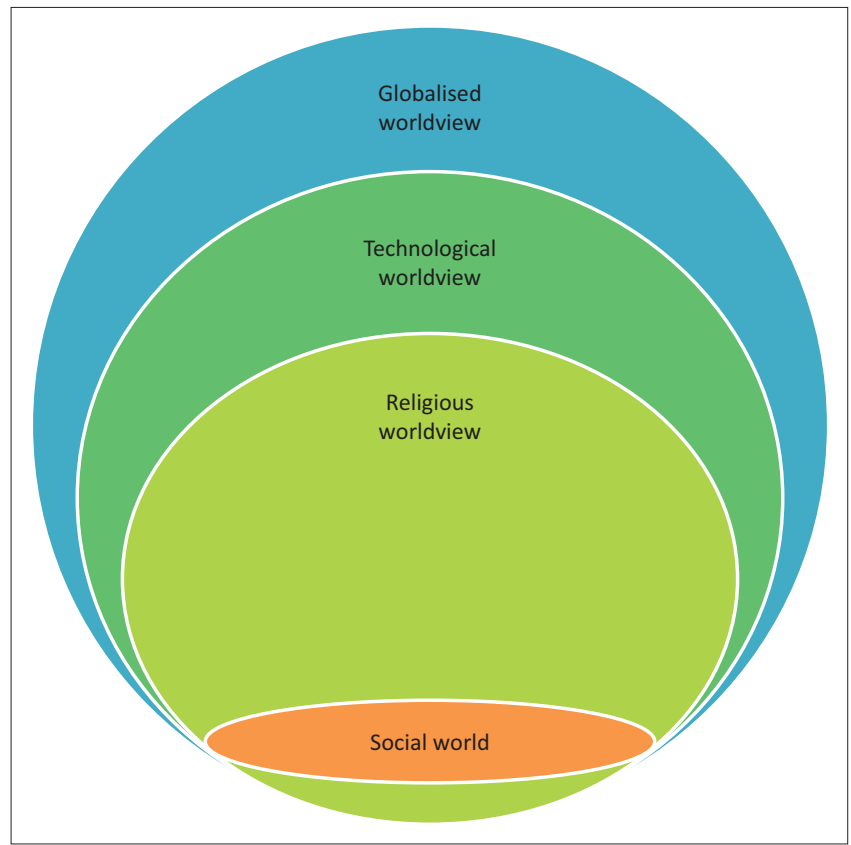

FIGURE 2: A symbolic multiverse of diverse worldviews spanning the social world.
Firstly, it can be concluded that these different views on the world constitute a multiverse, ${ }^{5}$ as these different worldviews are co-existing. Secondly, this observation can also be applied to the social word, which becomes somewhat fragmented into diverse but overlapping worlds with different activities, roles and relationships involved (Figure 3: Social multiverse).

These conclusions are compounded by the reality that individuals with different cultural and religious worlds may co-exist alongside each other, making the social multiverse even more diverse. It is important to note that the components of the social multiverse are not isolated from each other, but overlap with each other, suggesting constant dialogue and reciprocal influence on each other.

\section{Symbolic universe}

From a social-scientific viewpoint there are significant correspondences between the concepts of worldview and symbolic universe. Worlds are regarded as human constructions, with the focus on social arrangements and the symbolic forms that accompany them. 'Social arrangements' refer to the social structures underlying social relations, whilst 'symbolic forms' deal with the overarching cognitive systems, that is, the systems of knowledge, belief and value that define and motivate individuals' actions (Petersen 1985:ix-x; Van Staden 2015:n.p.).

A symbolic universe is the world as it is known; therefore this knowledge of the world shapes one's experience of it. The world does not exist apart from what is known. A symbolic universe is the 'world' as it is viewed, not as something that exists apart from the way we view it (Cromhout 2007:70;

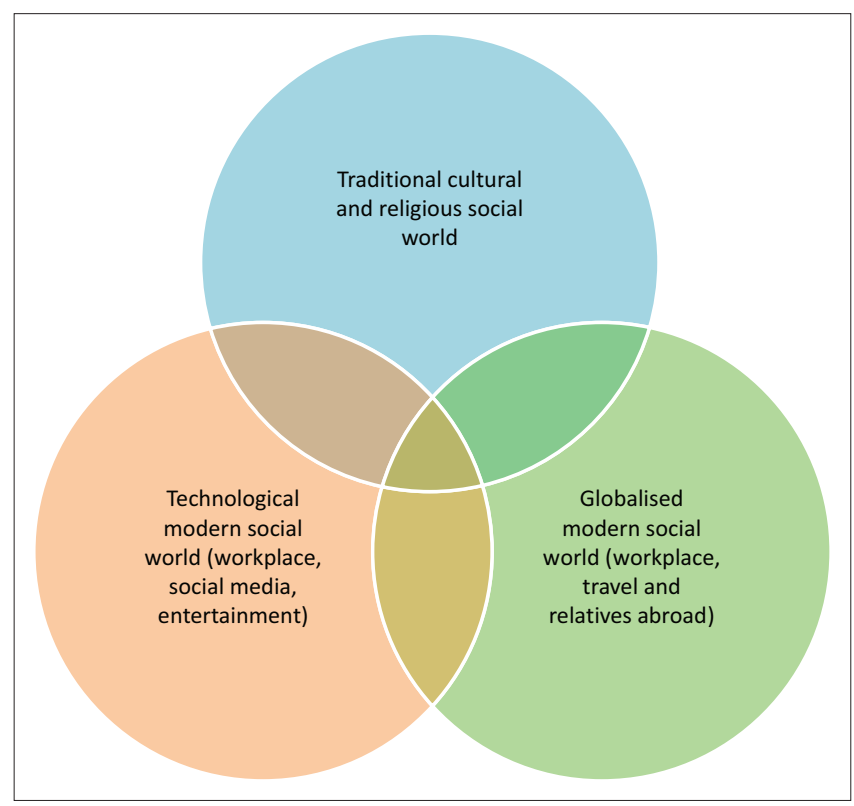

FIGURE 3: A social multiverse of individuals in a modern, globalised world.

5.The term 'multiverse' is borrowed from astronomy. The ever expanding universe is called a multiverse, which is constituted by a maze of also expanding universes, possibly with their own laws of physics, elementary particles and forces, probably possibly with their own laws of physics, elementary particles and forces, probably
distinctly different from our own universe (Greene 2000:366-370). 'Multiverse' is a distinctly different from our own universe (Greene 2000:366-370). 'Multiverse' is a
useful term to describe the plurality of symbolic and social universes of modern, globalised societies. 
Petersen 1985:29-30; Van Staden 2005:184-187). It is called 'symbolic', 'because the realities of everyday life are comprehended within the framework of other realities (Petersen 1985:59; Van Staden 2015:n.p.). Being symbolic, it is a phenomenon of culture, as culture relates to the sphere of the symbolic in society, namely the way that phenomena of everyday life are symbolised and endowed with meaning enabling them to refer beyond their regular signifieds. It represents the ultimate meaning that integrates all human experience and is a reality of which the objective existence can neither be described nor validated. The body of theoretical tradition about that reality can be studied, namely what people come to know about that 'ultimate reality' (Van Staden 2015:n.p., 1991:93).

Society cannot continue to function or survive as it does without symbolic universe providing its ultimate meaning, as they are all-embracing bodies of theoretical tradition that integrate different provinces of meaning and encompass the institutional order in a symbolic totality, thus forming the most comprehensive level of legitimation of society's institutional order. Legitimation occurs by producing and integrating meaning and explaining and justifying the social order to new generations. This framework forms a literal universe, a protective canopy, within which all human experience takes place (Van Staden 2015:n.p.). Produced by society it offers the ultimate theoretical protection for society's and individuals' continued orderly functioning and survival (Berger \& Luckmann [1967] 1975:113-120; Cromhout 2007:71). The necessity of symbolic universes for continued meaningful and orderly existence is applicable not only to society as a whole, but also to individuals within society.

When a symbolic universe is challenged by an alternative or deviant version, a systematic conceptualisation of the beleaguered symbolic universe is constructed in its defence (Berger \& Luckmann [1967] 1975:124-127; Petersen 1985:60; Van Staden 2015:n.p.). This is necessary, as the threat posed by an alternative interpretation of reality is that it demonstrates one's own universes as less than inevitable. The problem arises because inhabitants of a symbolic universe take it for granted and mostly leave it unquestioned. Universe maintenance is done by historically available methods in the following order: mythology, theology, philosophy and science. Mythology represents the most archaic and naïve form; theology is its more elaborate form, although theology is closer to philosophy, its secularised conception of reality, than it is to mythology. Modern science is the most extreme form, both in its removal of the sacred from universe maintenance and everyday life, and isolating universe-maintaining knowledge from the everyday world. It becomes the domain of the scientific elite, leaving the 'lay' members of society without knowledge of universes maintenance (Berger \& Luckmann [1967] 1975:127-130; Cromhout 2007:73-74).

It is important to note the pluralistic nature of modern societies, which has implications for their symbolic universes. Modern societies have a shared core universe taken for granted as such, and different partial universes coexisting in a state of mutual accommodation (Berger \& Luckmann [1967] 1975:142).

\section{Concluding remarks}

This investigation was undertaken in order to investigate whether different mythologies function as worldview and symbolic universes and whether they represent alternative and ASCs.

From the discussion of Weltanschauung and symbolic universes we can conclude that there is indeed a very strong link between the concepts mythology, worldview and symbolic universe. The following similarities can be noted:

- they serve as comprehensive frames of reference for societies and individuals

- they confer the meaning of life, society, social order, institutions and roles

- they explain why things are the way they are and society functions the way it does

- they legitimise social institutions and order

- they are cultural constructions

- they are cognitive constructions learned from previous generations

- they are internalised by individuals in a unique way

- they are self-maintaining and need not be legitimised

- they are certain perspectives (horizons) from which phenomena are interpreted

- they are plural in nature, leading to social and symbolic multiverses

- they can oppose each other or co-exist.

Mythologies can be described as symbolic universes and Weltanschauungen (worldviews), since both terminologies were developed in different disciplines with essentially the same semantic reference. The one can be regarded as synonymous with the others.

Because they are socially transmitted and practically function as frames of reference, we are correct to think of them as functioning on a conscious level, but the issue is more complex. The discussion about the conscious and unconscious motivations for human behaviour shows that societal ideas and values are represented by the superego. The ego utilises the learnt knowledge and perceptions into an organised rational system. The id represents socially unaccepted urges and wishes and is constantly in conflict with societal norms represented by the superego. The id's irrational urges can be described as a challenge to society's order and symbolic universe. Furthermore, unrepressed perceptions, memories and feelings reside in the pre-conscious. We can thus conclude that symbolic universes, mythologies and Weltanschauungen function on a conscious, preconscious and unconscious level. In this sense they can function on alternative levels of consciousness. As individuals are part of societies, we can state that societies' symbolic universes function on all levels of consciousness. As symbolic universes of cultures differ, their respective symbolic universes may be viewed as alternative states of consciousness. 
But can a symbolic universe be described as an altered state of consciousness? Is adherence to a religious worldview an altered state of consciousness in comparison to a secular worldview? It must be stated that the concept of worldview or symbolic universe function in the same way in both instances. The difference is that, with religion, we move to the sphere of the metaphysical, the realm where gods are encountered. This is also the realm in which most ASCs are experienced. If a secular worldview is used as a base line, a religious worldview can indeed be described as an altered state of consciousness, which the secular worldview is not. A symbolic universe per se can therefore not be described as an altered state of consciousness.

From the phenomenon of alternate modernities and the conclusion about symbolic and social multiverses we can state that within globalised, modern culture, some individuals may experience such multiverses, of which the religious ones are ASCs and the secular ones not.

Regarding Bultmann's view of Paul's conversion ([1948] 1980:189) we can state that Paul traded one symbolic universe for another. The change was so radical that his worldview (Selfbsverständnis) altered as he accepted the early Hellenistic church's mythological kerugma and thus entered from one altered state (Judaic religion) into another altered state of consciousness (Hellenistic Christian faith).

Van Aarde's view of Romans 12:1-2 (2015:87-116) as describing faith as 'an exceptional religious altered state of consciousness' can be endorsed, with the addition that any adherence to a religious worldview can be described as an altered state of consciousness.

\section{Acknowledgements \\ Competing interests}

The author declares that he has no financial or personal relationships which may have inappropriately influenced him in writing this article.

\section{References}

Aristotle, 1984, 'On the soul (trans J.A. Smith)', in J. Barnes (ed.), The complete works of Aristotle, vol. 1, Princeton University Press, Princeton, NJ.

Baars, B.J., 2002, 'The conscious access hypothesis: Origins and recent evidence', Trends in Cognitive Science 6, 47-52. http://dx.doi.org/10.1016/S1364-6613 (00)01819-2

Berger, P.L., 1973, The social reality of religion, Penguin, Harmondsworth.

Berger, P.L., 2003, 'Religions and globalisation', European Judaism 36(1), 4-10. http:// dx.doi.org/10.3167/001430003782266233

Berger, P.L. \& Luckmann, T., [1967] 1975, The social contruction of reality. A treatise in the sociology of knowledge, Penguin, Harmondsworth.

Bergmann, M.S., 2010, 'Philosophy and psychoanalysis', Issues in Psychoanalytic Psychology 32(1 \& 2), 53-72.

Bohleber, W., 2011, 'The dynamic unconscious in the analytic relationship: Response', International Journal of Psychoanalysis 92(2), 285-288.

Boly, M., Balteau, E., Schnakers, C., Deguelde, C., Moonen, G., Luxen, A. et al., 2007, 'Baseline brain activity fluctuations predict somatosensory perceptions in humans', Proceedings of the National Acadamy of Science of the United States of America 104(29), 12187-12192. http://dx.doi.org/10.1073/pnas.0611404104

Boly, M., Philips, C., Thsibanda, L., Vanhaudenhuise, A., Schabus, M., Dang-Vu, T.T. et al., 2008, 'Intrinsic brain activity and altered states of consciousness. How conscious is the default mode of brain function?, Annals of the New York Academy of Science 1129, 119-129. http://dx.doi.org/10.1196/annals.1417.015
Bourguignon, E., 1974, 'Cross-cultural perspectives on the religious uses of altered states of consciousness', in I.I. Zaretsky \& M.P. Leone (eds.), Religious movements in contemporary America, pp. 228-243, Princeton University Press, Princeton, NJ.

Bourguignon, E., 1979, 'Altered states of consciousness', in E. Bourguignon (ed.), Psychological anthropology: An introduction to human nature and cultural differences, pp. 233-269, Holt, Rhinehart \& Winston, New York, NY.

Brenner, C., 2007, 'Freud's great voyage of discovery', Psychoanalytic Quarterly LXXVI, 9-25. http://dx.doi.org/10.1002/j.2167-4086.2007.tb00243.x

Bultmann, R.K., [1948] 1980, Theologie des Neuen Testaments, 8th edn., Mohr, Tübingen.

Callicott, J.B., 2011, 'The worldview concept and Aldo Leopold's project of "world view" remediation', Journal for the Study of Religion, Nature and Culture 5(4), 510-528. http://dx.doi.org/10.1558/jsrnc.v5i4.509

Caston, V., 2002, 'Aristotle on consciousness', Mind 111(444), 751-815. http://dx.doi. org/10.1093/mind/111.444.751

Cromhout, M., 2007, Jesus and identity. Reconstructing Judean ethnicity in $Q$, James Clarke \& Co., Cambridge.

d'Aquili, E.G. \& Newberg, A.B., 1999, The mystical mind: Proving the biology of religious experience, Fortress, Minneapolis, $\mathrm{MN}$.

Dehaene, S. \& Changeux, J.P., 2005, 'Ongoing spontaneous activity controls access to consciousness: A neuronal model for inattentional blindness', Public Library of Science Biology 3(e141), 910-927. http://dx.doi.org/10.1371/journal.pbio. 0030141

Ekstrom, S., 2004, 'The mind beyond our immediate awareness: Freudian, Jungian, and Cognitive models of the unconscious', Journal of Analytical Psychology 49, 657-682. http://dx.doi.org/10.1111/j.0021-8774.2004.00494.x

English, F., 2008, 'Unconscious drives reimagined', Transactual Analysis Journal 38(3), 238-246.

Erickson, M.H. \&. Rossi E.L., 1981, Experiencing hypnosis: Therapeutic approaches to altered states, Irvington, New York.

Feest, U., 2012, 'Introspection as a method and introspection as a feature of consciousness', Inquiry 55(1), 1-16. http://dx.doi.org/10.1080/0020174X.2012. 643619

Fox, M.D., Snyder, A.Z., Vincent, J.L., Corbetta, M., Van Essen, D.C., \& Raichle, M.E. 2005, Proceedings of the National Acadamy of Science of the United States of America 102(27), 9673-9678. http://dx.doi.org/10.1073/pnas.0504136102

Freud, S., [1933] 1971, The new introductory lectures on psychoanalysis, Hogarth, London. (The Standard Edition of the Complete Works of Sigmund Freud).

Gammelgaard, J., 2003, 'The unconscious: A re-reading of the Freudian concept', Scandinavian Psychoanalytic Review 26, 11-21. http://dx.doi.org/10.1080/01062 301.2003.10592903

Gaster, T.H., 1962, 'Myth, mythology', in G.A. Buttrick (ed.), Interpreter's Dictionary of the Bible, vol. 3, pp. 481-487, Abingdon Press, New York.

Greene, B., 2000, The elegant universe, 2nd edn., Vintage, London.

Greenfield, S., 2001, 'Altered states of consciousness', Social Research 68(3), 609-626.

Groenewald, J., 2011, 'Show, tell and re-enact: The reason why the earliest followers of Jesus found the Eucharist meaningful', HTS Teologiese Studies/Theological Studies, 67(1), Art. no. 877, 10 p.

Gusnard, D.A. \& Raichle, M.E., 2001, 'Searching for a baseline: Functional imaging and the resting human brain', Nature Reviews Neuroscience 2, 685-694. http://dx.doi. org $/ 10.1038 / 35094500$

Hegel, G.W.F., [1820] 1991, Elements of the philosophy of right, Cambridge University Press, Cambridge.

Heidegger, M., [1927] 1996, Being and Time, State University of New York Press, New York, NY.

Hennig, B., 2010, 'Science, conscience, consciousness', History of Human Sciences 23(3), 15-28. http://dx.doi.org/10.1177/0952695110363353

Kant, I., [1781] 1984, Critique of pure reason, Everyman's Library, London.

Karilemla, 2015, 'Heidegger's contrasting notion of worldview in the early, middle and later writings', The Humanistic Psychologist 43(3), 250-266. http://dx.doi.org/10. 1080/08873267.2015.1047020

Krauze, M.K., 2011, 'The dynamic unconscious in the analytical relationship: Response', International Journal of Psychoanalysis 92(2), 283-285.

Krippner, S., 1972, 'Altered states of consciousness', in J. White (ed.), The highest state of consciousness, pp. 1-5, Doubleday, New York, NY.

Kruger, D., 1988, An introduction to phenomenological psychology, 2nd rev. edn., Juta, Cape Town.

Laureys, S., Faymonville, M.E., Luxen, A., Lamy, M., Franck, G. \& Maquet, P., 2000 'Restoration of thalamocortical connectivity after recovery from persistent vegetative state', The Lancet 355(9217), 1790-1791. http://dx.doi.org/10.1016/ S0140-6736(00)02271-6

Laureys, S., Goldman, S., Phillips, C., Van Bogaert, P., Aerts, J., Luxen, A., et al., 1999a, 'Impaired effective cortical connectivity in vegetative state: Preliminary investigation using PET', Neuroimage 9, 377-382. http://dx.doi.org/10.1016/ S0140-6736(00)02271-6

Laureys, S., Lemaire, C., Maquet, P., Phillips, C. \& Franck, G., 1999b, 'Cerebral metabolism during vegetative state and after recovery to consciousness', Journal of Neurology, Neurosurgery \& Psychiatry 67(1), 121-122. http://dx.doi. org/10.1006/nimg.1998.0414

Lothane, Z., 2006, 'Freud's Legacy - Is it still with us?' Psychoanalytic Psychology 23(2), 285-301. http://dx.doi.org/10.1037/0736-9735.23.2.285 
Malina, B.J. \& Rohrbaugh, L.R., 2003, Social-scientific commentary on the synoptic gospels, 2nd edn., Fortress, Minneapolis, MN.

Massimini, M., Ferrarelli, F., Huber, R., Esser, S.K., Singh, H. \& Tononi, G., 2005, 'Breakdown of cortical effective conectivity during sleep', Science 309(5744), 2228-2232. http://dx.doi.org/10.1126/science.1117256

McCarthy, V.A., 1978, The phenomenology of moods in Kierkegaard, Martinus Nijhoff, The Hague.

Meyer, W.F., 1988, 'Die psigoanalitiese teorie van Freud', in W.F. Meyer, C. Moore \& H.G. Viljoen (eds.), Persoonlikheidsteorieë van Freud tot Frankl, pp. 40-78, Lexicon, Johannesburg.

Nietzsche, F., [1874] 1980, On the advantage and disadvantage of history for life, Hacket, Indianapolis, IN.

Nietzsche, F., [1887] 2009, On the genealogy of morals: A polemical tract, Richter Resources, Arlington, TX.

Olivier, A., 2011, 'Phenomenology of the human condition', South African Journal of Philosophy 30 (2), 184-196. http://dx.doi.org/10.4314/sajpem.v30i2.67780

Petersen, N.R., 1985, Rediscovering Paul. Philemon and the sociology of Paul's narrative world, Fortress, Philadelphia, PA.

Phares, E.J., 1992, Clinical psychology. Concepts, methods, \& profession, 4th edn., Brooks/Cole, Pacific Grove, CA.

Pilch, J.J., 1993, 'Visions in Revelation and alternate consciousness', Listening: Journa for Religion and Culture 28(3), 231-244.

Pilch, J.J., 2000, 'Paul's ecstatic trance experience near Damascus in Acts of the Apostles', HTS Teologiese Studies/Theological Studies 58(2), 690-707.

Pilch, J.J., 2004, Visions and healing in the Acts of the Apostles: How the early believers experienced God, Liturgical Press, Collegeville, PA.

Plaut, A.B.J., 2005, 'Freud's "id" and Jung's "self" as aids in selfanalysis', Journal of Analytical Psychology 50, 69-82. http://dx.doi.org/10.1111/j.0021-8774.2005. 00512.x
Polito, V., Langdon, R. \& Brown, J., 2010, 'The experience of altered states of consciousness in shamanic ritual: The role of pre-existing beliefs and affective factors', Consciousness and Cognition 19, 918-925. http://dx.doi.org/10.1016/j.concog.2010.05.013

Power, M., 2000, 'Freud and the unconscious', The Psychologist 13(12), 612-614.

Robinson, D.N., 2010, 'Consciousness: The first frontier', Theory and Psychology 20(6),781-793. http://dx.doi.org/10.1177/0959354310369944

Stoycheva, V. \& Weinberger, J., 2014, 'The place of the normative unconscious in psychoanalytic theory and practice', Psychoanalytical Psychology 31(1), 100-118. http://dx.doi.org/10.1037/a0035372

Taylor, E., 2010, 'William James on a phenomenological psychology of immediate experience: The true foundation for a science of consciousness?' History of the Human Sciences 23(3), 119-130. http://dx.doi.org/10.1177/0952695110363644

Van Aarde, A.G., 2015, 'Faith as exceptional religious state of consciousness: A pragmatic linguistic reading of Romans $12^{\prime}$, in J. Van der Watt (ed.), The New Testament in the Graeco-Roman world. Articles in Honour of Abe Malherbe, pp. 87-116, Lit Verlag, Zuerich.

Van Staden, P., 1991, Compassion - the essence of life: A social-scientific study of the religious symbolic universe reflected in the ideology/theology of Luke, HTS Supplementum Series edition, Faculty of Theology (Section A), Pretoria University, Pretoria.

Van Staden, P., 2005, Towards a greater God. The evolution of religion, 2nd rev edition, Imaging Data Solutions, Cape Town.

Van Staden, P., 2015, 'Die heilige koepel', in Die Hervormer, November 2015, viewed 21 January 2016, from http://hervormer.co.za/index.php/ons-praat-teologie/150die-heilige-koepel

White, N.S. \& Alkire, M.T., 2003, 'Impaired thalamocortical connectivity in humans during general-anesthetic-induced unconsciousness', Neuroimage 19, 402-411. http://dx.doi.org/10.1016/S1053-8119(03)00103-4

Witz, K.G., 2015, 'Consciousness as a characteristic of the human being as a whole: Elements of a new approach', Qualitative Enquiry 21(7), 660-671. 